\title{
Causes and Consequences of Deep Structural Roots in Urban Trees: From Nursery Production to Landscape Establishment
}

\author{
Susan D. Day, Gary Watson, P. Eric Wiseman, and J. Roger Harris
}

\begin{abstract}
Recent research has improved our understanding of how structural roots of landscape trees respond to being located abnormally deep in the soil profile. This condition is widespread among landscape trees and may originate during nursery production, at transplanting into the landscape, or when construction fill or sediment deposits bury root systems of established trees. Deep structural roots sometimes hinder successful establishment of trees, occasionally enhance establishment, and often have little or no effect on growth or survival. When trees respond to deep structural roots, effects are sometimes observed when root collars are as little as $7.5 \mathrm{~cm}$ (3 in) deep. In some cases, deep structural roots are implicated in girdling root formation, but research in this area is quite limited. This review describes scientific progress in our understanding of deep structural roots and encompasses their history, causes, and significance, as well as interdisciplinary efforts to address deep planting and tree response during establishment to deep structural roots. A theoretical model of short-term tree response to deep structural roots is presented that helps explain these conflicting outcomes and provides a decision framework for practitioners evaluating trees with deep structural roots.

Key Words. Buried Roots; Deep Planting; Girdling Roots; Propagation; Root Architecture; Root Morphology; Urban Forestry.
\end{abstract}

Excess soil over root systems of landscape and urban trees has long been recognized as a hindrance for successful transplant establishment and long-term tree health. For example, reduced soil aeration in the root zone of established shade trees was attributed to compacted clay fill soil over forty-five years ago (Yelenosky 1963), and the recognition of decline in recently planted street trees with deep roots was first reported by Berrang et al. (1985).

The large woody roots giving characteristic form to the root system are commonly referred to as structural roots, skeletal roots, or scaffold roots (Sutton and Tinus 1983). For both newly planted and established trees, covering these roots with excess soil can alter the rhizosphere environment. In soils buried by compacted fill, oxygen concentration may decrease and carbon dioxide increase; however, these effects may be temporary and influenced by both soil moisture and time of year (Yelenosky 1963). Additional soil covering the roots can also intercept rainfall or irrigation, reducing soil water content in the root zone, particularly when fill is also covered with mulch (Arnold et al. 2005; Arnold et al. 2007; Gilman and Grabosky 2004), or is compacted (Day et al. 2001). Planting trees too deep with their root collars below soil grade can thus inhibit tree establishment and growth (Arnold et al. 2005; Arnold et al. 2007) or have no effect (Day and Harris 2008). In addition, deep planting has been shown to increase formation of girdling roots, a term generally used for roots in tight tangential contact with trunks (Giblin et al 2005; Wells et al. 2006; Day and Harris 2008); and trunk-soil contact due to deep planting or fill soil may increase the risk of disease infection. However, evidence of increased disease infection is limited (Smiley 1992) or contrary (Day et al. 2005). Finally, excess soil depth may be associated with increased risk of tree failure. Post-hurricane studies have found that trees with root-related failures were more likely to also have buried root collars than similar trees that did not fail (33\% versus 8\%) (Smiley 2005). However, it cannot be determined whether this was caused by burial of the root collar, or by an associated activity such as root severance during grading.

Although tree decline has often been attributed to deep or buried roots, relatively few published reports have actually evaluated the impact of excess soil on root systems. Tree response to buried root systems is likely dependent upon numerous interacting factors, including species, size, age, nursery production practices, planting practices, site conditions, soil properties, cultural practices, and tree stress from other sources such as pests. As a result, it is no surprise that making prognoses for trees with deep structural roots and prescribing effective treatments are so challenging. New research has been published in the last five years, especially in the area of transplant and establishment response to deep structural roots, which may change our perspective on this challenge. This paper focuses on deep structural roots in landscape trees during the period from nursery production through full establishment. The objective is to synthesize published research to provide a better understanding of the issues at play in nursery production, transplanting, and landscape establishment of trees to better serve prevention efforts and management of deep structural roots.

\section{DEEP STRUCTURAL ROOTS: HISTORY AND PREVALENCE}

\section{Deep Structural Roots in Nursery Production}

Deep structural roots sometimes originate during nursery production. Maynard (1995) reported trees leaving nurseries with 
structural roots 7.5 to $30 \mathrm{~cm}$ (3 to $12 \mathrm{in}$ ) deep in the root ball. Both Maynard's report and an earlier report by Berrang et al. (1985) attributed excess soil over the root collar to soil cultivation for weed control in the nursery. More recently, changes that occur to the structural root architecture during nursery production have also been identified as a possible cause (Hewitt and Watson 2009). Recent studies in Indiana, Ohio, North Carolina, and Tennessee (U.S.) indicate that the average depth of structural roots in nursery fields and harvested root balls ranges from 6 to $21 \mathrm{~cm}$ (2.5 to 8 in) (Airhart 2005; Rathjens et al. 2008). Depths of individual trees were not provided in these reports, but it is clear that many trees leave nurseries "deep in the ball."

\section{Deep Structural Roots in the Landscape}

Although several observational studies indicate that deep structural roots are prevalent in landscapes, each study is essentially a snapshot of a particular situation, and there is not sufficient information to identify either upward or downward trends in the prevalence of deep structural roots. Inspection of a planting site in the Chicago area in 1989 found $28 \%$ of recently planted trees had the first two structural roots at depths greater than $7.5 \mathrm{~cm}$ (3 in) while an inspection at a second site in 2004 found 63\% of trees with roots at these depths (Hewitt and Watson 2009). Employees of Bartlett Tree Research Laboratories (Charlotte, NC, U.S.) excavated 417 recently planted trees and found $93 \%$ had buried root collars, defined as the root flare not being visible above the soil. Average depth to first root varied from 7.5 $\mathrm{cm}$ in Charlotte, NC and Cape Cod, MA, to slightly over $15 \mathrm{~cm}$ (6 in) in Long Island, NY (Smiley 1991). In a Minnesota study of street trees with trunk diameters of $7.5-22.5 \mathrm{~cm}$ (3-9 in), $20 \%-58 \%$ of trees had the uppermost structural roots more than $7.5 \mathrm{~cm}$ below ground (Giblin et al. 2005). None of the studies examine the relative contribution of nursery production methods and planting practices to deep structural roots in installed trees.

It is not clear how deep roots became so prevalent in landscape tree nurseries and in established trees, but propagation practices and reforestation techniques may have contributed. In reforestation plantings, it is common practice to plant seedlings [usually 20-30 cm (8-12 in) tall] much deeper than they existed in the nursery, sometimes with only the terminal bud above ground (Slocum and Maki 1956; McGee and Hatcher 1963; Stroempl 1990), unless the site is poorly drained (Koshi 1960; Switzer 1960). Deep planting has been shown to increase survival and growth in these circumstances, presumably because of better access to moist soil and protection of the collar. "Deep" planting of such small stock, however, usually results in roots being placed only a few centimeters deeper than normal, and is therefore not comparable to deep structural roots in landscape-sized trees. In addition, this practice with these very young plants may be comparable to the nursery propagation technique of rooting stem cuttings, where stem tissue is plunged several centimeters deep into propagation media to initiate rooting. In this practice, root primordia usually form in the phloem parenchyma cells of the stem (Hartmann et al. 2002). In some species, more mature stock can lose this ability to produce new roots from the stem. Small rooted cuttings ( $<1$ year old) of live oak (Quercus virginiana) retained their ability to produce new roots from the stem, but the same plants did not produce new roots from the stem a year later when buried deeper in container media (Gilman and Harchick 2008).
Other species, such as coast redwood (Sequoia sempervirens), can retain this ability throughout their life (Stone and Vasey 1968).

Other specialized horticultural practices also use deep planting to achieve specific results. For example, trees in fruit orchards may be planted with the roots up to $20 \mathrm{~cm}$ ( 8 in) deep so that the graft (bud) union can be buried and consequently protected from desiccation and physical damage (Lyons and Yoder 1981). These authors noted that changes in grafting technique in which trees were budded $13-18 \mathrm{~cm}(5-7$ in) up from the root collar compared to earlier practices of $<5 \mathrm{~cm}$ (2 in) resulted in deeper planting when growers used the bud union as a reference point for planting depth. Deep planting will slow growth of fruit trees (Lyons et al. 1982; Lyons et al. 1983), and is sometimes done deliberately for this purpose (Lyons et al. 1987). Although it is not recorded in the published literature, these historically common forestry and horticultural practices may have served as precedent for structural roots being placed deep during nursery production and in subsequent planting into the landscape.

\section{Professional Response to Deep Structural Roots}

In the early 2000s, industry concern over the effects of deep structural roots in urban and suburban landscapes reached a critical level. Because deep structural roots are so prevalent, it is assumed that problems associated with these buried roots may ultimately have widespread and long-lasting effects on urban forest health and safety. Municipalities, in particular, rely on transplanting large trees ( $>2 \mathrm{~m}$ in height) to build their urban forests (Harris 2007). Unlike reforestation seedlings and naturally occurring seedlings, there are multiple opportunities for large planted trees to have their structural roots placed too deep in the soil, both during multiple steps in nursery production and at transplanting. Because the longterm health of these trees is critical to achieving survival and canopy coverage goals, a national green industry working group was formed in the United States to address the issue (Watson 2005b). Green industry professional organizations, including the American Nursery and Landscape Association, the American Society of Landscape Architects, the International Society of Arboriculture, and the Associated Landscape Contractors of America (now part of the Professional Landcare Network) opened dialogue concerning prevention of deep structural roots in landscape trees. During the same period, language was added to the American Standard for Nursery Stock (ANSI Z60.1) addressing root flare depth of balled-and-burlapped nursery stock (ANSI Z60.1 American Standard for Nursery Stock 2004). As a result of the working group, a Best Management Practice (BMP) booklet for identifying deep root systems in nursery stock was developed (Watson 2005b).

Another component of this initiative has been a coordinated effort to fill knowledge gaps through research. The Morton Arboretum (Lisle, IL, U.S.) convened a meeting of researchers in November 2005 (Watson 2005a) to open communication between researchers investigating aspects of deep root problems. This meeting was funded in part by the USDA Forest Service upon the recommendation of the National Urban and Community Forestry Advisory Council. New research continues to emerge and, partly as a result of this initiative, information is now available that may reshape our views on deep structural roots and the implications for arboriculture. 


\section{DEEP STRUCTURAL ROOTS: NURSERY PRODUCTION ISSUES}

Tree root development in a natural forest environment differs markedly from that in a nursery production environment. When a seed falls to the ground and germinates, the primary root emerges from the seed and grows down in response to gravity. Growth of the primary root slows when it encounters the denser, less aerated conditions of deeper soil regions. Such growth cessation may occur quite close to the surface in compacted or poorly drained soils, especially in species with weak primary roots. Roots may grow somewhat deeper in strong taprooted species and on well-drained sites. As growth of the primary root slows, small lateral roots form near the soil surface (Eshel and Waisel 1996; Stokes 2000), eventually forming the root flare or collar.

Though many nursery trees and rootstocks are also propagated by seed, the rooting environment is utterly different from most natural ecosystems. The common production process is to manipulate the root system repeatedly by successive pruning and transplanting events in order to produce a more compact and thus more easily transplanted tree. In field production, trees are frequently grown for one or two seasons in seedbeds, after which they are mechanically harvested and the primary root is pruned to a depth of about $10 \mathrm{~cm}$ (4 in). In response to primary root pruning, new roots generate predominantly from the cut end, but occasionally higher up on the primary root (Harris et al. 2001). Most of the natural lateral roots above the cut end do not persist; thus the newly-generated roots become the primary lateral roots, forming an "adventitious root flare" (Hewitt and Watson 2009) (Figure 1). These early changes in root architecture are important because the major roots established during the first few years constitute the main structural root system (Coutts 1983).

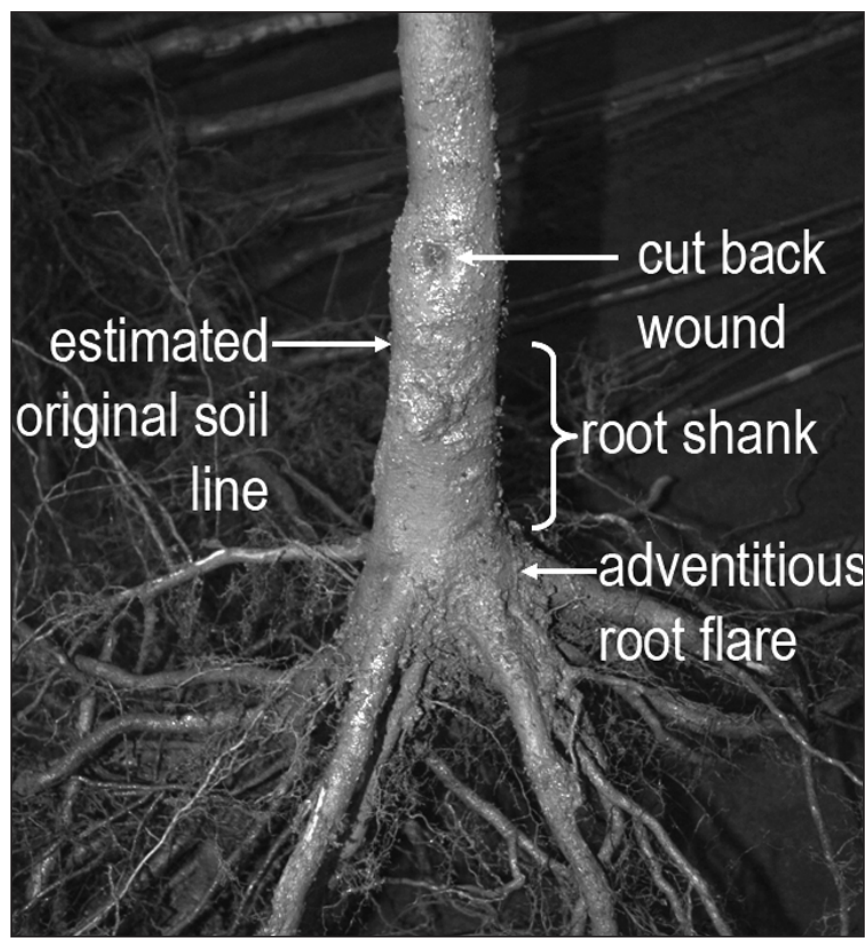

Figure 1. Excavated root system of approximately four-year-old nursery tree showing root and trunk regions resulting from propagation and nursery production practices.
Seedlings are then planted in rows, maintaining the same root depth as in the seedling bed. Typically after one year of growth in the field, the top of the tree is cut back to a low lateral bud so that next year's growth will be vigorous, resulting in a straight trunk, except where the shoot originated. This area where the young vigorous trunk meets the rootstock ultimately becomes the "dogleg" visible on young nursery trees. This characteristic also holds true for the graft union on grafted cultivars. Nursery operators prune young shade trees in this way to take advantage of the fact that the root system has already been established for a year before cutting back and the new shoot growth is rapid. The stem can be trained into a single straight trunk in one year to produce a "whip" or "liner," which is then transplanted into the field or containers for growth to saleable size. This above- and belowground pruning can thus create two identifiable portions of the trunk/root system not normally seen in undisturbed seedlings: the "dogleg" or jog in the lower trunk and the "root shank," a carrot-like portion of the upper primary root that has few or no lateral roots.

During production, the length of the "root shank" and morphology of main lateral roots can be affected by root pruning practices. For example, Harris et al. (2001) found that severity of root pruning during early growth of pin oak seedlings (Quercus palustris) was positively correlated with the number of main lateral roots formed. However, very severe root pruning (to $5 \mathrm{~cm}$ below soil) also reduced both root and shoot dry weights. Because most roots generate from the cut end, choice of root pruning depth must balance the effects on root shank length and lateral root formation against maintaining vigor in the plant. In container production of very young trees (liners), growth of primary roots is usually stopped by air pruning, in which exposure to air kills back the growing root tip, rather than by mechanical pruning. When the tip is killed, limited regeneration will occur from the tap root or radicle because of these same unfavorable conditions, although intact lateral roots will continue to proliferate. Similar artificial stagnation of taproot growth in experiments has encouraged growth of lateral roots sooner than on seedlings where radicles were allowed to continue growing (Eshel and Waisel 1996). This may lead to a less pronounced adventitious root flare and more lateral roots closer to the soil surface. Rathjens et al. (2008) found that the depth of the main lateral roots of nursery trees varied by nursery, but not by production method, i.e. seed vs. cutting vs. budding. This suggests that variations in production techniques early on may influence structural root depth. Whether these differences were related to the length of the root shank is unknown.

A long root shank can create the situation at planting where, if the structural roots are placed near the soil surface, a portion of the root shank will be above ground. This raises the question, "Is it root or shoot?" Perhaps a more direct question is, "Does the root shank need to be gradually acclimated to exposure or protected from the elements?" This is a controversial question among many growers and arborists and to the knowledge of this paper's authors, has not been addressed by published research. The transition from root tissue to shoot tissue can be a gradual one. Bark characteristics can change gradually and may depend upon exposure to soil. For example, a comparison of root and shoot bark anatomy in English oak (Quercus robur), revealed that there were relatively few structural or anatomical differences between root and stem bark overall: the zone of cell differentiation was wider in root bark, the root phelloderm was more distinct, sclereid quantity decreased with increasing distance from the stem, and 
secondary phloem fibers were slightly shorter than those in stem bark (Trockenbrodt 1995). Of particular relevance to the characteristics of the root shank, the taproot bark near ground level (less than $40 \mathrm{~cm}$ deep) was similar to mature, thick stem bark and exhibited a distinct rhytidome, or outer bark. Lateral roots, on the other hand, did not form a rhytidome. Research is meager in this area, and studies directly applicable to root shank questions, especially winter hardiness considerations, are essential.

When liners are planted in the field for growing to saleable size, many growers purposely plant the liners too deep for several reasons: to reduce the need for staking, to control sprouts from rootstocks, to protect the bud union, or to hide the crook in the stem that resulted from the grafting and cutback process. In addition, nursery maintenance and harvesting practices may contribute to deep root systems. Unlike the forest where the soil is protected from drying by leaf litter "mulch," frequent drying of bare nursery surface soils may inhibit root development near the surface. Cultivation in nurseries for weed control can also discourage root growth near the soil surface and may mound soil around the base of trees. If not removed before harvesting, this soil can bury structural roots in the root ball.

When field-grown bare root liners are planted into containers for growing to saleable size, the structural roots can easily be too deep, sometimes resulting in reduced growth (Fare 2005). Fine roots originating from the structural root system can proliferate in the container substrate above the structural roots (Fare 2005), making transplanting "at grade" difficult unless these roots are severed. In addition, deep planting during container production may result in poor quality trees. Gilman and Harchick (2008) found that planting live oak deep in the container during production produced circling roots such that they did not meet the minimum quality of the Florida Grades and Standards for Nursery Stock (Florida Department of Agriculture and Consumer Services 1998). This effect was most pronounced in the most deeply planted trees.

\section{DEEP STRUCTURAL ROOTS: LANDSCAPE ESTABLISHMENT ISSUES}

Deep planting can improve establishment (Slocum and Maki 1956; Harms 1969), have no effect on establishment (Day and Harris 2008) or be detrimental to establishment (Arnold et al. 2007). Studies demonstrating improved establishment from deep planting are typically limited to small reforestation seedlings where "deep" planting is a matter of $5-10 \mathrm{~cm}(2-4$ in) because of the small stature of the plants (Harms 1969; Macadam and Bedford 1998). Recently, however, Dreesen and Fenchel (2008) reported that the USDA Natural Resources Conservation Service has developed a system for revegetating riparian zones in arid climates that relies on tall nursery stock $[2.6 \mathrm{~m}$ $(8.5 \mathrm{ft})]$ being planted in $2 \mathrm{~m}(6.6 \mathrm{ft})$ holes, i.e. approximately $1.6 \mathrm{~m}(5.25 \mathrm{ft})$ too deep, in order to access deep water tables in sandy soils. This technique resulted in successful establishment of hackberry (Celtis laevigata) and box-elder (Acer negundo), but no comparisons were made with trees planted at grade. Landscape-sized trees in landscape sites, the subject of this review, generally do not respond as favorably as these examples. These trees have already developed an extensive root system and are subject to establishment periods of several years once transplanted into the landscape. In addition, the soil conditions around a deeply-planted rootball are often unfavorable for root growth in many sites (Harris 2007), especially in urbanized areas where extensive grading and topsoil removal are common.

When conditions lower in the soil profile are less favorable than those near the surface, deep planting can inhibit establishment. Arnold et al. (2007) found that planting small [9.3 1 ( 3 gal)], container-grown trees as little as $7.5 \mathrm{~cm}$ below grade decreased survival and growth of all but one of five species after three years in a sandy loam underlain at $15-30 \mathrm{~cm}(6-12$ in) with a hard clay pan in Texas. The clay pan in this layered soil was punctured during planting hole excavation, suggesting that the root systems of the deeply planted trees were partly surrounded by clay. Growth increased in some instances for trees planted above grade, suggesting that minimizing exposure to the clay hardpan may have been beneficial. An earlier study produced similar results, but also found that increased mulch depth reduced growth, apparently because rainfall was unable to adequately penetrate the soil in order to reach the deep-planted roots (Arnold et al. 2005). In a seven-month establishment study with large, $\sim 7.6 \mathrm{~cm}$ ( 3 in) trunk diameter, field-grown live oak, tree growth was unaffected by planting as much as $18 \mathrm{~cm}$ (7 in) below grade in a fine sand soil. However, deep-planted trees experienced greater water deficits than trees planted at grade when lightly irrigated after an extended dry period. This irrigation event was apparently unable to penetrate down to the deep root balls, even in sandy field soils (Gilman and Grabosky 2004).

These results suggest that the interaction of climate and soil properties at differing depths are primary factors influencing survival and growth of deep-planted trees during the establishment period. For example, if lower soil regions were highly compacted, very wet, or very dry, establishment would likely be impaired, especially in species sensitive to the particular conditions present. With the exception of girdling roots, all effects shown to arise from deep planting to date (see Table 1) can be understood in the context of species response to the immediate conditions encountered by the transplanted root system. On the other hand, when no exacerbating conditions are present, trees may grow normally for many years. For example, in the first five years of a study with Turkish hazel (Corylus colurna), growth and establishment of trees planted both 15 and $30 \mathrm{~cm}$ deep were essentially identical to trees planted at grade. But after two severe flooding events, $40 \%$ of the most deeply planted trees died compared with no deaths among trees planted at grade or only $15 \mathrm{~cm}$ (6 in) deep (Day and Harris 2008). Tree establishment may also be unaffected if the species in question can tolerate the adverse soil conditions present in the lower regions of the site. For example, red maple (Acer rubrum) is a very flood-tolerant tree (Whitlow and Harris 1979), while Yoshino cherry (Prunus $\times$ yedoensis) is not (Ranney 1994). When these two species were planted $30 \mathrm{~cm}$ (12 in) below grade on a slope where drainage was poorer on the lower end of the slope, all red maples survived, while deep-planted cherries died in much greater numbers during establishment than at-grade trees (50\% versus none), especially on the lower end of the slope (Wells et al. 2006).

The conditions encountered in lower soil regions may vary considerably and arguably play a much more important role in tree establishment and survival than previously thought. Urban soils disturbed by cut-and-fill practices may have lower soil layers that are very wet or very dry (Day et al. 2001). Even undisturbed soil profiles can have denser horizons with lower organic matter (B and $\mathrm{C}$ horizons) within about $30 \mathrm{~cm}$ 
Table 1. Minimum depth of root collar where effect of deep structural roots was demonstrated for various species. Effects observed and possible contributing factors are summarized. Reports that showed no effects are not listed and are instead discussed in the text. Some studies did not include shallower depths than those indicated. Only controlled experiments demonstrating the effect described was due to deep structural roots are listed.

\begin{tabular}{|c|c|c|c|c|}
\hline Species & $\begin{array}{l}\text { Minimum depth } \\
\text { of root collar where } \\
\text { effect was evident } \\
(\mathrm{cm})\end{array}$ & $\begin{array}{l}\text { Possible contributing } \\
\text { factors }\end{array}$ & Effects observed & Published Report \\
\hline Acer rubrum & 15 & $\begin{array}{l}\text { Adventitious root } \\
\text { formation }\end{array}$ & $\begin{array}{l}\text { Increase in girdling } \\
\text { roots }\end{array}$ & (Wells et al. 2006) \\
\hline Corylus colurna & 15 & None & Girdling root present & (Day and Harris 2008) \\
\hline Corylus colurna & $\begin{array}{l}30 \\
\text { (not observed at 15) }\end{array}$ & Flooding & $\begin{array}{l}\text { Mortality of } \\
\text { established trees } \\
\text { associated with flooding }\end{array}$ & (Day and Harris 2008) \\
\hline $\begin{array}{l}\text { Lagerstroemia indica } \times \\
\text { faureiei; Fraxinus pensylvanica; } \\
\text { Nerium oleander; } \\
\text { Platanus occidentalis }\end{array}$ & 7.5 & $\begin{array}{l}\text { Clay soils, trees rely } \\
\text { on irrigation }\end{array}$ & $\begin{array}{l}\text { Lower survival } 3 \text { years } \\
\text { after transplant }\end{array}$ & (Arnold et al. 2007) \\
\hline Quercus virginiana & $\begin{array}{l}\text { No minimum depth, } \\
\text { effect increased with } \\
\text { planting depth up to } \\
\text { maximum tested of } \\
18 \mathrm{~cm}\end{array}$ & $\begin{array}{l}\text { Only occurred when } \\
\text { minimal irrigation was } \\
\text { supplied after a dry period } \\
\text { - effect therefore } \\
\text { attributed to water not } \\
\text { reaching rootball }\end{array}$ & $\begin{array}{l}\text { Decrease in plant water } \\
\text { potential (water stress) }\end{array}$ & $\begin{array}{l}\text { (Gilman and } \\
\text { Grabosky 2004) }\end{array}$ \\
\hline Phoenix roebelenii & 30 (not observed at 15$)$ & $\begin{array}{l}\text { Root initiation zone } \\
\text { extends } 15 \mathrm{~cm} \text { up the } \\
\text { trunk on these trees }\end{array}$ & $\begin{array}{l}\text { Foliar Mn deficiency, } \\
\text { reduced survival }\end{array}$ & (Broschat 1995) \\
\hline Prunus $\times$ yedoensis & 15 & $\begin{array}{l}\text { Wet soils-effect was } \\
\text { exacerbated on lower } \\
\text { portion of the slope }\end{array}$ & $\begin{array}{l}\text { Increased mortality } \\
\text { during establishment }\end{array}$ & (Wells et al. 2006) \\
\hline
\end{tabular}

of the surface. In extreme cases, deep, penetrable, or fractured soils may allow tree root growth as far as $60 \mathrm{~m}(197 \mathrm{ft})$ down (Jackson 1999). Such conditions are unlikely in an urban setting, although urban subterranean infrastructure can create some unusual root pathways, but such events underscore the importance of considering soil conditions of each site independently rather than developing generalized prognoses for all situations.

\section{Palms}

Deep planting of palms is a common practice (Menge and Brown 1992). Palms are monocots and most species generate adventitious roots from root initials on the trunk at transplanting, rather than relying entirely on root generation from the severed roots within a transplanted rootball. Consequently, small root balls often transplant successfully, allowing successful transplanting of large trees. Palms are often planted deeply to increase stability and to adjust height to suit architectural preferences, such as staggered or uniform heights. The root initiation zone typically extends some distance up the trunk. One study has examined this practice and found that planting at grade or slightly deeper (burying the root initials $>15-30 \mathrm{~cm}$ ) resulted in optimal growth and survival for pygmy date palms (Phoenix roebeleinii), a species native to dry sites (Broschat 1995). Planting deeper than the optimum depth decreased survival and growth, apparently for the same reasons noted for dicots: the root system was located in an unfavorable growing region. In addition, root generation from the root initiation zone decreased when this portion of the trunk was planted into lower soil regions. The highest mortality was seen in trees planted $90 \mathrm{~cm}$ ( $3 \mathrm{ft}$ ) deep, where they were periodically exposed to a high water table (Broschat 1995). This suggests that deeper, wetter soil zones not only created environmental stress for the original root ball on this species, but also for new adventitious roots.

In contrast, cabbage palm (Sabal palmetto) is native to wetlands and will grow in standing water. In addition, cabbage palm generates almost no root tips from cut roots; thus establishment relies almost exclusively on new adventitious roots (Broschat and Donselman 1984). Nonetheless, Costonis observed a $99 \%$ mortality rate for cabbage palms planted into a wet muck soil, most of which were planted 25 to $255 \mathrm{~cm}$ (10 to 100 in) below grade (Costonis 1995). Subsequent replanting using a variety of transplanting techniques [but all at $10-15 \mathrm{~cm}$ (4-6 in) above grade] resulted in near $100 \%$ survival. Unfortunately, the study did not include a control for planting depth, so it cannot be determined whether this, or another factor such as plant handling, played a role in transplant success. In addition, direct compari- 
sons with subsequent plantings are not appropriate since, for example, quality of the palms, handling, and weather may all have been different. A former landscape contractor in Florida reports routinely planting cabbage palms (S. palmetto) 100 to $130 \mathrm{~cm}$ ( 3 to $4 \mathrm{ft}$ ) deep in sandy soils. In one instance they observed roots growing out of the entire planted portion of the trunk when a deep planted tree was later moved (pers. comm., from coauthor, J. R. Harris), thus indicating that it is possible for the root initiation zone to extend more than a meter up the trunk.

\section{Adventitious Roots on Dicot Trees}

Many dicots, such as London planetree (Platanus $\times$ occidentalis) and red maple (Acer rubrum) can form adventitious roots when moist soil is placed against the trunk. Propagation by stem cuttings is a common means of nursery production for these and other species. It is possible that such an adventitious root system would form on these deeply planted species while the original root system serves as an establishing or "nurse" root system. No scientific studies of such phenomena have been reported. In addition, the response of palms to such practices suggests that species tolerance to the environmental conditions of lower soil regions must always be taken into account.

Mature trees that have been buried by changes in soil grade sometimes form new adventitious root systems (e.g., Platanus $\times$ occidentalis, personal observation of the authors). This also occurs in natural ecosystems subject to alluvial or windblown soil deposition (Stone and Vasey 1968; Filion and Marin 1998). In urban landscapes, however, cases have been observed where such adventitious root systems support the tree physiologically but not structurally. In one such case, described by Harris et al. (2004), when the original roots decayed, the tree was taken down. A systematic analysis of this phenomenon has apparently not been made. However, deep-planted trees have also been reported to be less stable if adventitious roots do not form on the buried stem (Lyons and Yoder 1981).

\section{Root Structure}

Deep planting creates the potential for roots to grow upwards through the soil and come in contact with the trunk. When roots are in tight tangential contact with the trunk, they are generally termed girdling roots even when the trunk is not fully encircled. Deep structural roots have been observed to increase the incidence of girdling roots, but this appears to be at least partially species dependent (Wells et al. 2006) and possibly time dependent (Watson 1990; Day and Harris 2008). Although poor root structure may be detrimental to trees in the long term, it is not believed to be a factor influencing the initial establishment of landscape trees.

\section{Trunk-Soil Contact}

Unless soil is held back by a tree well or retaining wall, deeply planted trees invariably will have soil in direct contact with the trunk. Mulch piled against the trunk creates an analogous situation. Does this trunk/substrate contact increase infection by soilborne pathogens such as Phytophthora spp.? Some diseases, such as Sphaeropsis tip blight, can be harbored in cone-bearing mulch resulting in increased disease incidence in pines (Jacobs 2005). Wells et al. (2006) observed sporadic Phytopthora infection on deeply planted Prunus $\times$ yedoensis; but whether the infection was related to trunk/soil contact or to the increased susceptibility of stressed trees could not be determined. Mortality was high among deeply planted trees and infection was also present on trees planted at grade. Day et al. (2005) used bark biopsies to assess fungi present on white oak (Quercus alba) and sweetgum (Liquidambar styraciflua) trunks nine years after burial by construction fill. Oak bark was observed to be decaying, but only saprophytic fungi (Penicillium spp., Trichoderma spp., and Pestalotia spp.) were recovered. In contrast, no fungi were recovered from sweetgum bark, which was visually unchanged from unburied trees. Drilias et al (1982) observed urban sugar maples (Acer saccharum) in Wisconsin, U.S. infected with Fusarium and Phytopthora species that causes "basal rot" and "collar rot." They found a high incidence of disease in urban maples, many of which had buried root collars, and no infection in comparable woodland trees. The authors concluded that an unidentified factor associated with urban trees increased incidence of these diseases and suggested nursery production and deep planting as possible topics of future research. Indeed, for a given site, some of the environmental factors that can contribute to infection by a particular disease, for example flooding and Phytopthora in apples (Browne and Mircetich 1988), may be present in deeper soil regions but not in shallower regions.

\section{Optimal Depth of Structural Roots}

"How deep is too deep?" still remains a question of some controversy. Roots must be covered by some soil or other media if they are to take up water and nutrients, generate secondary roots, be protected from temperature and moisture extremes, and provide stability. On the other hand, deep structural roots can adversely affect tree development. In the studies analyzed in this review, effects were typically seen only when root collars were $15 \mathrm{~cm}$ or more deep. The shallowest depth having any apparent impact in any situation was $7.5 \mathrm{~cm}$ (Table 1). It must be emphasized, however, that few studies examined a range of depths within 0-15 cm (0-6 in). Effects also vary by species, soil type, and climate. The $B M P$ for identifying deep root systems in nursery stock is based on the depth to the first two structural roots (less than $7.5 \mathrm{~cm}$ deep, measured $7.5-10 \mathrm{~cm}$ out from the trunk), while the establishment studies cited here refer to the depth of the root collar. Thus a tree planted $7.5 \mathrm{~cm}$ too deep, may have the first structural root position several centimeters below that.

\section{A Model for Understanding Deep Structural Roots}

Two principle changes occur when trees are planted too deep: 1) planting exposes tree roots to a different environment than that near the soil surface and, 2) trunk tissue is in contact with soil. These two principle components create a framework for understanding the effects of deep planting on tree establishment and for forming field prognoses for short-term survival (Figure 2). This framework helps explain the often conflicting results from research studies and aids the practitioner in assessing the consequences of deep structural roots. To use this model, practitioners must know the soil conditions at the depth where the structural roots have been placed, and also understand the site tolerances of the particular tree species. This model can be refined and expanded as more research becomes available assessing the long-term effects of girdling roots, remediation practices, and the influence of species' ability to form adventitious roots. 


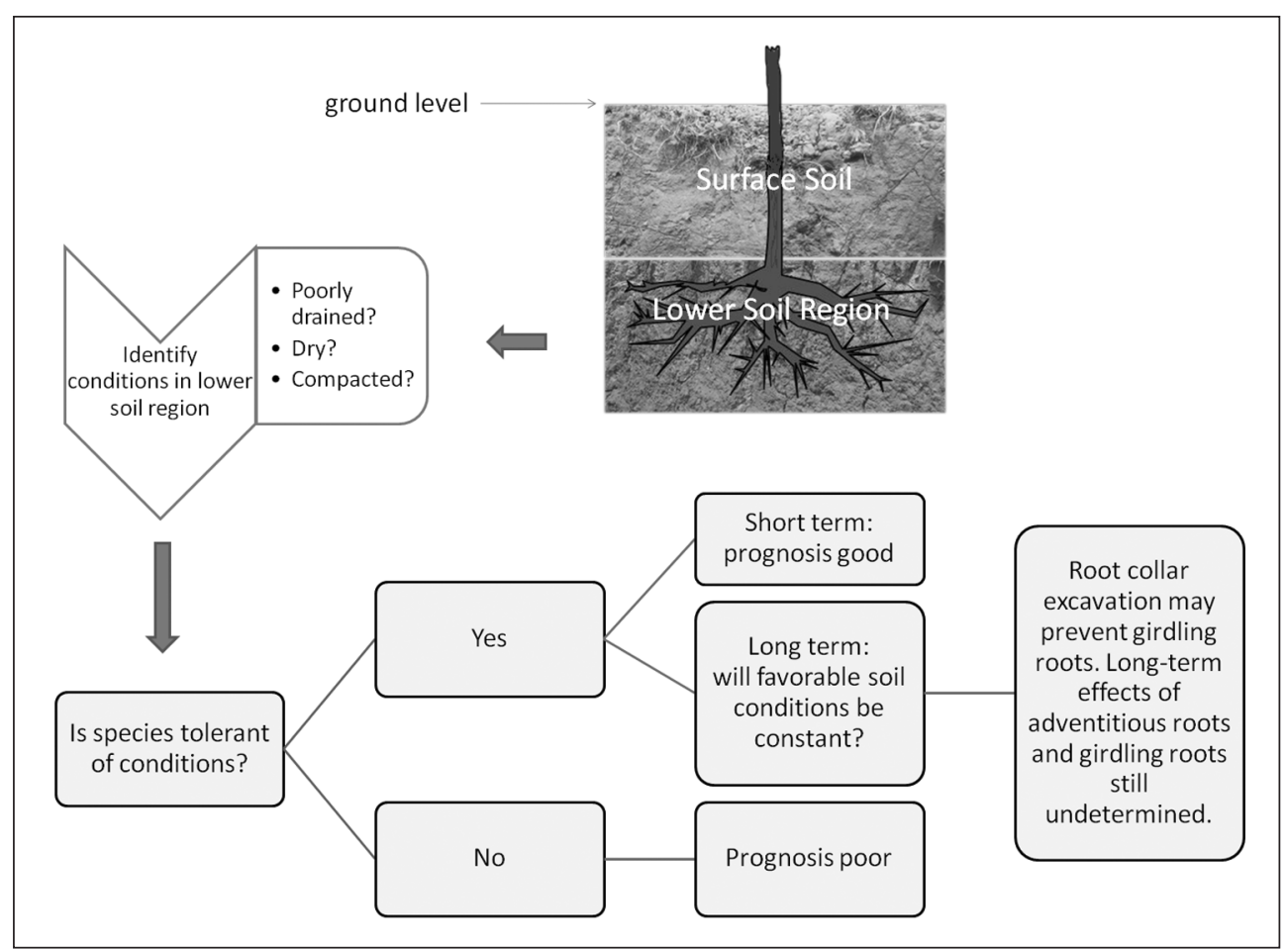

Figure 2. Framework for predicting establishment and short-term survival and health of landscape trees with deep structural roots.

\section{FUTURE INVESTIGATION}

Although recent research has greatly clarified our understanding of how trees respond to burial of the structural root system, there are many questions that remain to be answered, especially concerning remediation and tree stability. For example, research has now documented that deeper planting can increase prevalence of girdling roots (e.g., Wells et al. 2006; Day and Harris 2008), but the long-term effects of such roots are unknown. They can compress xylem, reducing vascular transport and subsequent physiological function (Hudler and Beale 1981). On the other hand, there is some indication that girdling roots may not persist over time (Watson 1990). Furthermore, in severe cases they are difficult to remove without inflicting unnacceptable injury to the tree and may simply reoccur from the point of removal (Watson and Clark 1993). This study suggests the following research themes are high priority for advancing arborists' ability to diagnose and treat trees with deep structural roots.

Research Theme: Structural stability of trees relying on adventitious root systems - especially as it relates to size of tree when such root systems were initiated.

Practical questions addressed: Should young trees planted deep and now relying on adventitious root systems be replaced because problems may eventually arise? Are adventitious root systems formed on large trees inherently weak? If they are, how weak and what should be done about it?

Research Theme: Long-term persistence and effect of girdling roots.
Practical questions addressed: What is the prognosis for trees with girdling roots? Should they be artificially weakened, or inspected over time to see if they senesce?

Research Theme: The effect of root collar excavations and analysis of whether removing adventitious roots during this process is detrimental or beneficial to tree health and stability.

Practical questions addressed: When should a root collar excavation be performed and what benefits can be expected? What size roots, if any, should be removed in a root collar excavation. How can the structural stability of larger trees be assessed?

Research Theme: The effects of tree age, species, and soil conditions on all of the above.

Practical questions addressed: Arborists could answer questions above for specific trees they are diagnosing. This understanding of individual tree circumstances and knowing that one size doesn't "fit all" is the hallmark of the science and art of arboriculture.

Research Theme: Impact of deep structural roots on urban and community canopy cover.

Practical questions addressed: Is the continuation of practices that contribute to deep structural roots having an impact on our ability to provide tree canopy along the streets of towns and cities? Can lost canopy be quantified such that the economic, environmental, and social costs of this practice can be described?

\section{CONCLUSIONS}

Increasing tree canopy coverage in human-dominated landscapes requires that transplanted trees establish well and remain healthy and stable over a long lifespan. Recent published research indicates that by understanding the environmental conditions of the soil regions where deep roots are placed and the tolerance of the species in question for these conditions, practitioners can make informed judgments about tree establishment and early growth. Trees are long-lived, however, and may be affected many years later by weather or other events. The efficacy of remedial treatments for deep structural roots, such as removing soil from the base of the trunk, is not well understood at this time. In addition, the effect of deep structural roots, adventitious roots, girdling roots, and remedial treatments on tree stability is also relatively unexplored. However, research is expected to emerge in the coming years that will provide a strong foundation for addressing deep structural roots in the long term. 
Acknowledgments. The authors are indebted to the members of the National Working Group on Deep Structural Roots for their dedication to and enthusiasm for moving science and collaboration forward to improve our understanding of deep roots. This effort was supported in part by the USDA Forest Service Urban and Community Forestry Grants Program under advisement of the National Urban and Community Forestry Advisory Council.

\section{LITERATURE CITED}

Airhart, D. 2005. Nursery tree depth projects. p. 10 In: Getting the Roots Right. The Morton Arboretum, Lisle, IL.

ANSI Z60.1 American Standard for Nursery Stock. 2004. American Nursery and Landscape Association.

Arnold, M.A., G.V. McDonald, and D.L. Bryan. 2005. Planting depth and mulch thickness affect establishment of green ash (Fraxinus pennsylvanica) and bougainvillea goldenraintree (Koelreuteria bipinnata). Journal of Arboriculture 31(4):163-170.

Arnold, M.A., G.V. McDonald, D.L. Bryan, G.C. Denny, W.T. Watson, and L. Lombardini. 2007. Below-grade planting adversely affects survival and growth of tree species from five different families. Arboriculture \& Urban Forestry 33(1):64-69.

Berrang, P., D.F. Karnosky, and B.J. Stanton. 1985. Environmental factors affecting tree health in New York City. Journal of Arboriculture 11(6):185-189.

Broschat, T.K. 1995. Planting depth affects survival, root growth, and nutrient content of transplanted pygmy date palms. HortScience 30(5):1031-1032.

Broschat, T.K., and H.M. Donselman. 1984. Regrowth of severed palm roots. Journal of Arboriculture 10(8):238-240.

Browne, G.T., and S.M. Mircetich. 1988. Effects of flood duration on the development of Phytopthora root and crown rots of apple. Phytopathology 78:846-851.

Costonis, A.C. 1995. Factors affecting the survival of transplanted sabal palms. Journal of Arboriculture 21(2):98-103.

Coutts, M. P. 1983. Development of the structural root system of Sitka spruce. Forestry 56(1):1-16.

Day, S.D., and J.R. Harris. 2008. Growth, survival, and root system morphology of deeply planted Corylus colurna seven years after transplanting and the effects of root collar excavation. Urban Forestry \& Urban Greening 7(2):119-128.

Day, S.D., J.R. Harris, and R.J. Stipes. 2005. Buried trunks: How deep planting affects trunk tissue, adventitious rooting, and tree growth. pp. 45-48 In: Getting the Roots Right. The Morton Arboretum, Lisle, IL

Day, S.D., J.R. Seiler, R. Kreh, and D.W. Smith. 2001. Overlaying compacted or uncompacted construction fill has no negative impact on white oak and sweetgum growth and physiology. Canadian Journal of Forest Research-Revue Canadienne De Recherche Forestiere 31(1):100-109.

Dreesen, D. R. and G. A. Fenchel. 2008. Deep-planting methods that require minimal or no irrigation to establish riparian trees and shrubs in the Southwest. Journal of Soil and Water Conservation (Ankeny) 63(4):129A-133A.

Drilias, M.J., J.E. Kuntz, and G.L. Worf. 1982. Collar rot and basal canker of sugar maple. Journal of Arboriculture 8(2):29-33.

Eshel, A., and Y. Waisel. 1996. Multiform and multifunction of various constitutents of one root system. p. 1002 In: Plant Roots: The Hidden Half. Y. Waisel, A. Eshel, and U. Kafkafi, Eds. Marcel Dekker, Inc., New York, NY.

Fare, D. 2005. Should potting depth be a concern with container-grown trees? pp. 25-28 In: Getting the Roots Right. The Morton Arboretum, Lisle, IL.
Filion, L., and P. Marin. 1988. Modifications morphologiques de l'Épinette blanche soumise à la sédimentation éolienne en milieu dunaire, Québec subarctique. Canadian Journal of Botany 66:1862-1869.

Florida Department of Agriculture and Consumer Services. 1998. Florida Grades and Standards for Nursery Stock. Gainesville, FL.

Giblin, C., J. Gillman, D. Hanson, G.R. Johnson, and P. Weicherding. 2005. The effects of soil depth on the long-term health and frequency of storm damage to trees in the Upper Midwest. pp. 33-39 In: Trees and Planting: Getting the Roots Right. The Morton Arboretum, Lisle, IL.

Gilman, E.F., and J. Grabosky. 2004. Mulch and planting depth affect live oak (Quercus virginiana Mill.) establishment. Journal of Arboriculture 30(5):311-317.

Gilman, E.F., and C. Harchick. 2008. Planting depth in containers affects root form and tree quality. Journal of Environmental Horticulture 26(3):129-134.

Harms, W.R. 1969. Deep planting of slash pine in the Carolina sandhills. Journal of Forestry 67:160-160.

Harris, J.R. 2007. Transplanting large trees. CAB Reviews: Perspectives in Agriculture, Veterinary Science, Nutrition and Natural Resources 2(024).

Harris, J.R., J. Fanelli, A. Niemiera, and R. Wright. 2001. Root pruning pin oak liners affects growth and root morphology. HortTechnology 11(1):49-52.

Harris, R.W., J.R. Clark, and N.P. Matheny. 2004. p. 269 In: Arboriculture: Integrated Management of Landscape Trees, Shrubs, and Vines. 4th Ed. Prentice-Hall, Inc., Upper Saddle River, NJ.

Hartmann, H.T., D.E. Kester, F.T. Davies, Jr., and R.L. Geneve. 2002. Plant Propagation: Principles and Practices. 7th Ed. Prentice Hall, Upper Saddle River, NJ, p. 284.

Hewitt, A. and G. Watson. 2009. Bare root liner production can alter tree root architecture. Journal of Environmental Horticulture 27:99-104.

Hudler, G.W., and M.A. Beale. 1981. Anatomical features of girdling root injury. Journal of Arboriculture 7(2):29-32.

Jackson, R.B., L.A. Moore, W.A. Hoffmann, W.T. Pockman, and C.R. Linder. 1999. Ecosystem rooting depth determined with caves and DNA. Proceedings of the National Academy of Science USA 96:11387-11392

Jacobs, K. 2005. The potential of mulch to transmit three tree pathogens. Journal of Arboriculture 31(5):235-242.

Koshi, P.T. 1960. Deep planting has little effect in a wet year. Tree Planters' Notes 11:7.

Lyons, C.G., R.E. Byers, and K.S. Yoder. 1987. Influence of planting depth on growth of young apple trees. Journal of Environmental Horticulture 5(4):163-164.

Lyons, C.G., Jr., R.E. Byers, and K.S. Yoder. 1983. Influence of planting depth on growth and anchorage of young 'Delicious' apple trees. HortScience 18(6):923-924.

Lyons, C.G., Jr. and K.S. Yoder. 1981. Poor anchorage of deeply planted peach trees. HortScience 16(1):48-49.

Lyons, C.G., Jr., K.S. Yoder, and R.E. Byers. 1982. Growth of mechanically planted nectarines planted at various depths. HortScience 17(6):968 969.

Macadam, A. and L. Bedford. 1998. Mounding in the sub-boreal spruce zone of west-central British Columbia: 8-year results. Forestry Chronicle 74(3):421-427.

Maynard, B.K. 1995. A problem of great depth...some nursery production practices may be leading to trees being planted too deeply. Yankee Nursery Quarterly 5(2):1-4.

McGee, C.E., and J.B. Hatcher. 1963. Deep-planting small slash pine on old field sites in the Carolina sandhills. Journal of Forestry 61(5):382-383. 
Menge, J.T., and K.E. Brown. 1992. Commercial transplanting of wild cabbage palms, Sabal palmetto, in Florida. Principes 36(2):94-98.

Ranney, T.G. 1994. Differential tolerance of eleven Prunus taxa to root zone flooding. Journal of Environmental Horticulture 12(3):138-141.

Rathjens, R.G., T.D. Sydnor, and D.S. Gardner. 2008. A survey of the depth of the main lateral roots of nursery trees in Ohio before and after harvest. Journal of Environmental Horticulture 25(4):187-190.

Slocum, G.K., and T.E. Maki. 1956. Some effects of depth of planting upon loblolly pine in the North Carolina Piedmont. Journal of Forestry 54:21-25.

Smiley, E. T. 1991. National epidemic reported: Improper planting is killing trees. Arbor Age 11(12):38-39.

Smiley, E.T. 1992. Root collar disorders. Bartlett Tree Research Laboratories, Charlotte, NC.

Smiley, E.T. 2005. Root collar excavations to improve tree health. pp. 4950 In: Getting the Roots Right. The Morton Arboretum, Lisle, IL.

Stokes, A. 2000. Strain distribution during anchorage failure of Pinus pinaster Ait. at different ages and tree growth response to wind-induced root movement. p. 426 In: The Suppporting Roots of Trees and Woody Plants: Form, Function, and Physiology. A. Stokes, Ed. Kluwer Academic, Dordrecht.

Stone, E.C., and R.B. Vasey. 1968. Preservation of coast redwood on alluvial flats. Science 159(3811):157-161.

Stroempl, G. 1990. Deeper planting of seedlings and transplants increases plantation survival. Tree Planters' Notes 41(4):17-21.

Sutton, R.F. and R.W. Tinus. 1983. Root and root system terminology. Forest Science 29(4):supplement (Monograph 24).

Switzer, G.L. 1960. Exposure and planting depth effects on loblolly pine planting stock on poorly drained sites. Journal of Forestry 61:390-391.

Trockenbrodt, M. 1995. Structure and identification of root bark of Quercus robur L. Trees: Structure and Function 9:341-347.

Watson, G. 1990. Formation of girdling roots. Journal of Arboriculture 16(8):197-202.

Watson, G. 2005a. Deep Roots of Landscape Trees: A comprehensive guide to current research and practice. The Morton Arboretum, Lisle, IL.

Watson, G. 2005b. Getting the roots right: The structural root depth best management practice. pp. 52-53 In: Trees and Planting: Getting the Roots Right. The Morton Arboretum, Lisle, IL.
Watson, G., and S. Clark. 1993. Regeneration of girdling roots after corrective treatment. Journal of Arboriculture 19:278-280.

Wells, C., K. Townsend, J. Caldwell, D. Ham, E.T. Smiley, and M. Sherwood. 2006. Effects of planting depth on landscape tree survival and girdling root formation. Arboriculture \& Urban Forestry 32(6):305-311.

Whitlow, T.H., and R.W. Harris. 1979. Flood tolerance in plants: a stateof-the-art review. in Environmental and Water Quality Operational Studies. U.S. Army Corps of Engineers.

Yelenosky, G. 1963. Soil aeration and tree growth. Proceedings of the International Shade Tree Conference 39:16-25.

Susan D. Day (corresponding author)

Assistant Professor

Department of Forestry

Department of Horticulture

Virginia Tech

228 Cheatham Hall

Blacksburg, Virginia 24061, U.S.

sdd@vt.edu

Gary Watson

Senior Research Scientist

The Morton Arboretum

Lisle, Illinois, U.S.

P. Eric Wiseman

Assistant Professor

Department of Forestry

Virginia Tech

228 Cheatham Hall

Blacksburg, Virginia 24061, U.S.

\section{J. Roger Harris}

Professor

Department of Horticulture

Virginia Tech

301 Saunders Hall

Blacksburg, Virginia 24061, U.S. 
Résumé. Une recherche récente a permis d'améliorer notre compréhension sur comment les racines structurales des arbres ornementaux répondent lorsqu'elles sont localisées anormalement en profondeur dans le profil de sol. Cette situation est largement répandue parmi les arbres ornementaux et pourrait tirer son origine lors de la production en pépinière, lors de la plantation ou encore lorsqu'un remblai du terrain est fait autour d'arbres existants lors de travaux de construction. Les racines structurales profondes gênent parfois la reprise des arbres plantés, occasionnellement améliore leur reprise et souvent n'a que peu ou pas d'effet sur la croissance ou la survie. Lorsque les arbres répondent à des racines structurales en profondeur, des effets sont parfois observés pas des collets racinaires aussi faibles que $7,5 \mathrm{~cm}$ sous le niveau du sol. Dans certains cas, des racines structurales profondes sont impliquées dans la formation de racines strangulantes, mais la recherche dans ce domaine est plutôt limitée. Cette revue décrit la progression scientifique dans notre compréhension des racines structurales profondes et ce qui entoure leur histoire, leur cause et leur signification tout comme les efforts interdisciplinaires par rapport à la plantation en profondeur et la réponse de l'arbre durant sa reprise en regard des racines structurales en profondeur. Un modèle théorique de réponse de l'arbre aux racines structurales en profondeur est présenté et il constitue une aide pour expliquer ces conflits qui surviennent ainsi que pour fournir un cadre décisionnel pour les praticiens qui doivent évaluer des arbres avec un enracinement structural en profondeur.

Zusammenfassung. Die jüngste Forschung hat entscheidend unsere Kenntnisse erweitert, wie Starkwurzeln von Bäumen reagieren, wenn sie abnorm tief in das Bodenprofil verlegt werden. Diese Bedingung ist unter Straßenbäumen weit verbreitet und mag aus der ursprünglich aus der Baumschule stammen, bei der Verpflanzung ins Freiland, oder wenn Rückverfüllungen oder Sedimentreste die Wurzeln praktisch begraben. Tiefe Starkwurzeln behindern manchmal die erfolgreiche Etablierung, gelegentlich verbessern sie die Etablierung und oft haben sie nur wenig oder gar keinen Effekt auf das Überleben. Wenn die Bäume auf tief liegende Starkwurzeln reagieren, können gelegentlich Auswirkun- gen beobachtet werden, wenn die Wurzelkragen ca. 7,5 cm tief liegen. In einigen Fällen sind tief liegende Starkwurzeln an der Bildung von Würgewurzeln beteiligt, aber dieser Bereich ist noch relativ unerforscht. Dieser Rückblick beschreibt den wissenschaftlichen Fortschritt in unserem Verständnis von tief liegenden Starkwurzeln und richtet ihre Geschichte, Gründe und Bedeutung, genauso wie die interdisziplinären Anstrengungen, tiefes Pflanzen und Baumreaktion während der Etablierung von tief liegenden Starkwurzeln anzusprechen. Ein theoretisches Modell von kurzfristigen Baumreaktionen auf tief liegende Starkwurzeln wird hier präsentiert. Es hilft bei der Klärung dieser Konflikt-reichen Ergebnisse und liefert einen Entscheidungsrahmen für Praktiker, Bäume mit tief sitzenden Starkwurzeln zu bewerten.

Resumen. La investigación más reciente ha mejorado nuestro entendimiento de cómo las raíces estructurales de los árboles en el paisaje responden cuando están anormalmente profundas en el perfil del suelo. Esta condición está ampliamente distribuida en los árboles urbanos y puede originarse durante la producción en los viveros, en el trasplante, o cuando los rellenos de construcción o depósitos de sedimentos entierran los sistemas de raíces de los árboles establecidos. Las raíces estructurales profundas algunas veces obstaculizan el éxito del establecimiento de los árboles, ocasionalmente el mejoramiento del mismo, y con frecuencia tienen poco o no afectan el crecimiento y sobrevivencia. Cuando los árboles responden a las raíces estructurales profundas, los efectos son algunas veces observados cuando las coronas de las raíces están a $7.5 \mathrm{~cm} \mathrm{(3}$ pulg) de profundidad. En algunos casos, las raíces profundas están implicadas en la formación de raíces estranguladoras, pero la investigación en esta área es aún limitada. Esta revisión describe los progresos científicos en nuestro entendimiento de la profundidad de las raíces estructurales y su historia, causas y significancia; como también los esfuerzos interdisciplinarios para dirigir la profundidad de la plantación y la respuesta del árbol durante el establecimiento. Se presenta un modelo teórico de respuesta a corto plazo que ayuda a explicar este conflicto en la toma de decisiones. 